Aksiologiya: Jurnal Pengabdian Kepada Masyarakat

Vol.5, No. 2, Mei 2021 Hal 191 - 202

ISSN 2528-4967 (print) dan ISSN 2548-219X (online)

\title{
Sosialisasi dan Edukasi Digital Marketing pada Komunitas BGBJ di Bantar Gebang Menghadapi Era 4.0
}

\author{
Janette Maria Pinariya ${ }^{1}$, Dianda Forceila ${ }^{2}$, Lystia Ivana ${ }^{3}$, Anita Yunia ${ }^{4}$ \\ Institut Komunikasi dan Bisnis LSPR \\ Email: janette.mp@1spr.edu ${ }^{1}$, diandraforceila@gmail.com², \\ ivanalystia25@gmail.com³, anita.y@1spr.edu ${ }^{4}$ \\ *Corresponding author: janette.mp@1spr.edu ${ }^{1}$
}

\begin{abstract}
ABSTRAK
Tujuan dari kegiatan ini adalah untuk mengatasi masalah yang sedang berkembang di Bantar Gebang yaitu sebagai salah satu wilayah daerah Bekasi yang dijadikan sebagai tempat pembuangan sampah terakhir kawasan megapolitan Jabodetabek. Bantar Gebang selama ini dikenal sebagai daerah kumuh dengan kondisi perekonomian masyarakat bertaraf rendah (miskin). Sehingga muncul inisiatif anak-anak muda untuk membentuk suatu komunitas usaha kecil dengan memanfaatkan limbah kayu, plastik, dan kertas sebagai bahan dasar pembuatan produk kreatif, yaitu komunitas The Kingdom of BGBJ (Biji-Biji Bantar Gebang). BGBJ dibangun atas bantuan, dukungan, dan dedikasi para pengunjungnya. Komunitas ini menyediakan berbagai pelatihan, pendampingan, bantuan sandang, papan dan pangan untuk masyarakat yang tidak memiliki akses ke sumber daya ini. Dengan adanya kegiatan pemberdayaan ini, diharapkan dapat memberikan alternatif bagi masyarakat untuk memutus siklus kemiskinan serta menciptakan lingkungan yang sehat dan aman. Namun untuk dapat mengembangkan program ini, BGBJ mengakui bahwa sumber daya yang dimilikinya belum paham akan strategi pemasaran. Hal ini dapat dilihat dari kegiatan pemasarannya yang hanya dilakukan sebatas pada komunikasi offline yaitu Word of Mouth (WoM). Dengan permasalahan tersebut, maka dibuatlah suatu program pemberdayaan kepada peserta komunitas BGBJ dan masyarakat tentang pemahaman pemasaran digital (digital marketing) serta kegiatan pendukung lainnya yang bermanfaat. Metode pelaksanaan kegiatan dilakukan dengan pendekatan model community development yang diberikan dalam bentuk sosialisasi dan edukasi serta pelatihan dan pendampingan selama 3 bulan, terhitung dari bulan Juni - Agustus 2020. Hasil menunjukkan bahwa kegiatan pemberdayaan ini dapat diterima secara efektif dan para peserta dinilai sudah siap untuk beradaptasi menghadapi era 4.0. Hal ini dapat diukur berdasarkan survei yang dilakukan sebelum maupun setelah kegiatan pemberdayaan dilakukan. Meskipun demikian, terdapat evaluasi bahwa pengembangan program ini harus dilakukan secara berkelanjutan, dikarenakan masih terdapat sebagian peserta yang memerlukan arahan dan bimbingan lebih lanjut.
\end{abstract}

Kata kunci: BGBJ; digital; media sosial; strategi pemasaran; 4.0.

\section{Socialization and Digital Marketing Education to the BGBJ Community in Bantar Gebang Facing Era 4.0}

ABSTRACT

The purpose of this activity is to address a growing problem in Bantar Gebang, known as one of the Bekasi areas which is used as the final waste disposal site for the Jabodetabek megapolitan area. Bantar Gebang has been known as a slum area with low economic conditions (poor). So that the initiative of young people emerged to form a small business community by utilizing wood, 
plastic, and paper waste as basic materials for making creative products, they are The Kingdom of BGBJ (Bantar Gebang Seeds) Community. BGBJ was built on the help, support and dedication of its visitors. This community provides a variety of training, mentoring, clothing, shelter and food assistance for people who do not have access to these resources. With this empowerment, it is hoped that it can provide an alternative for the community to break the cycle of poverty and create a healthy and safe environment. However, to be able to develop this program, BGBJ admits that its resources do not understand the marketing strategy. This can be seen from its marketing activities which are only limited to offline Word of Mouth (WoM) communication. With these problems, an empowerment program was made for BGBJ community participants and the public regarding the understanding of digital marketing (digital marketing) and other useful supporting activities. The method of implementing activities is carried out with a community development model approach which is given in the form of socialization and education as well as training and mentoring for 3 months, starting from June - August 2020. The result showed that the empowerment activity can be accepted effectively, and the participants are considered ready to adapt to the 4.0 era. This can be measured based on a survey conducted before and after the empowerment activity was carried out. However, there is an evaluation that the development of this program must be carried out continuously, because there are still some participants who need further direction and guidance.

Keywords: BGBJ; digital; social media; marketing strategy; 4.0.

\section{PENDAHULUAN}

Jakarta merupakan kota metropolitan yang memiliki beragam peran dan fungsi yang disandangnya. Jakarta bersama kota-kota di sekitarnya seperti Bogor, Depok, Tangerang, dan Bekasi telah menjadi kawasan megapolitan Jabodetabek (Jakarta Kota Metropolitan Dengan Budaya Kampung, 2013). Hampir seluruh markas utama perusahaan besar nasional maupun internasional berlokasi di Jakarta, sehingga hal ini menempatkan posisi Jakarta sebagai pusat perdagangan dan jasa di Indonesia. Meskipun demikian, Jakarta selalu memiliki ragam cerita dan masalah di dalamnya, mulai dari kemacetan, kehidupan sosial yang kurang merata, ditambah persoalan sampah yang selalu membuat resah masyarakat (Harahap, 2019).

Ir. Suharti M.A. PhD selaku DeputiGubernur Bidang Pengendalian Kependudukan dan Kepemukiman Pemprov DKIJakarta(Nursastri,2019) menyebutkan bahwa produksi sampah di Jakarta hampir setiap tahunnya terus mengalami peningkatan di mana dalam satu harinya dapat memproduksi hingga 7.700 ton sampah. Terutama pada suatu wilayah yang dijadikan sebagai tempat pembuangan sampah terakhir di Ibu Kota, yakni TPST Bantar Gebang yang memiliki luas sebesar 108 $\mathrm{Ha}$ (Fakhrana, 2015). Kerumunan sampah yang ada di wilayah ini mencapai jumlah kapasitas maksimal yang ada sehingga menimbulkan berbagai dampak buruk, baik dalam segi ekonomi, sosial, maupun lingkungan.

Bantar Gebang selama ini dikenal sebagai daerah kumuh dengan kondisi perekonomian masyarakat bertaraf rendah (miskin). Dalam (Mulyadi, 2016) ditemukan sekitar $72 \%$ orang tua memilih untuk mempekerjakan anaknya sebagai pengumpul sampah, 19\% memilih untuk sekolah tanpa dibebani kerja pengumpul sampah, dan 9\% sisanya memilih untuk dipekerjakan dan tidak sekolah.

Dalam mendukung komitmen pemerintah dalam melaksanakan Sustainable Development Goals (SDG), diperlukan keterlibatan 
seluruh pihak agar pelaksanaan dan pencapaian SGDs dapat dilaksanakan secara aktif. SDGs merupakan suatu rencana aksi global yang disepakati oleh para pemimpin dunia, termasuk Indonesia, guna mengakhiri kemiskinan, mengurangi kesenjangan dan melindungi lingkungan.

Langkah ini menjadi acuan utama untuk melakukan program pemberdayaan kepada salah satu komunitas di Bantar Gebang, yakni The Kingdom of BGBJ (Biji-Biji Bantar Gebang). Komunitas ini dibangun dengan bantuan, dukungan, dan dedikasi para pengunjungnya. BGBJ menyediakan pendidikan, pelatihan, bantuan, makanan, dan kesenangan untuk anak-anak yang tidak memiliki akses ke sumber daya ini.

Setiap hari Minggu, BGBJ menjalankan kelas dalam berbagai topik, seperti pelatihan bahasa inggris, informasi dan teknologi (IT), kesehatan dan nutrisi, olahraga, musik dan seni. Kemudian lokakarya lantai atas BGBJ digunakan sebagai ruang pendidikan untuk mengembangkan keterampilan praktis, dan merupakan latar tempat pembuatan lini produk 'BGBJ Style'. Produk ini terdiri dari "komponen gaya hidup", seperti dekorasi dan perabotan rumah, aksesori fesyen dan produk perawatan tubuh alami, di mana beberapa produk tersebut dibuat dengan memanfaatkan limbah yang ada. Sama halnya seperti artikel (Yunia \& Pinariya, 2019) yang juga menerapkan pemberdayaan masyarakat kepada klien pascarehabilitasi narkoba di
Tanjung Priok. Klien pascarehabilitasi yang telah menjalani masa rehab akan diberikan pelatihan-pelatihan pembuatan sovenirkreatifsepertikotak tisu, seni dekopas, paper bag, pouch yang mana bahan dasarnya merupakan limbah ramah lingkungan.

Meskipun telah menghasilkan banyak produk, BGBJ mengakui bahwa dirinya masih belum memiliki pemahaman yang cukup mengenai tata cara pemasaran produk dengan menggunakan media digital. Di era perdagangan bebas ini, berbagai kompetisi terbuka secara lebar antara pelaku bisnis yang mana dapat menghasilkan dua hal kemungkinan, yaitu peluang atau ancaman. Hal ini dapat diatasi apabila pelaku bisnis dapat menerapkan komunikasi pemasarandenganbaik. Meningkatnya ekonomi kreatif dan ekonomi digital di era 4.0, strategi pemasaran melalui media sosial seperti facebook, Instagram, aplikasi berbasis web telah menjadi trend baru di masyarakat (Christiawan, 2019). Saat ini, banyak organisasi maupun perusahaan yang telah menggunakan media digital tidak hanya untuk berkomunikasi dengan rekan kerja, melainkan dengan calon pelanggannya.

Meskipun BGBJ sudah memiliki situs pribadi dan media sosial, kegiatan pemasaran yang dilakukan dianggap belum mumpuni dikarenakan strategi pemasaran yang digunakan lebih berfokus pada model komunikasi offline salah satunya berasal dari Word of Mouth (WoM). Tidak hanya itu, pendiri BGBJ mengungkapkan bahwa keterbatasan SDM yang 
kurang kompeten di dunia digital juga menjadi hambatan dalam proses pemasaran produk. Hingga saat ini, BGBJ menyebutkan bahwa produk yang dihasilkan cukup banyak, namun karena keterbatasan pemahaman serta pemanfaatan media digital membuat keberlangsungan komunitas tetap jalan di tempat. Dengan latar belakang tersebut, maka dibuatlah suatu program pemberdayaan digital marketing kepada peserta dan masyarakat Bantar Gebang, khususnya pada usia remaja tentang pemasaran produk melalui media digital dengan mempresentasikan sekaligus membuatkan modul mengenai langkah-langkah proses pembuatan hingga tahap eksekusi yang diharapkan dapat memberikan kontribusi komunitas BGBJ dalam mengembangkan jalur pemasaran produk di era 4.0.

\section{METODE PELAKSANAAN}

Kegiatan pemberdayaan masyarakat ini merupakan salah satu program yang melibatkan salah satu komunitas yang berada di Bantar Gebang, yaitu The Kingdom of BGBJ. Pelaksaaan kegiatan dilakukan dalam waktu tiga bulan, dimulai dari bulan Juni sampai Agustus 2020. Kegiatan ini dilakukan dengan menggunakan pendekatan model community development yaitu "upaya mempersiapkan masyarakat seiring dengan langkah memperkuat kelembagaan masyarakat agar mereka mampu mewujudkan kemajuan, kemandirian, dan kesejahteraan dalam suasana keadilan sosial yang berkelanjutan" (Sumaryadi, 2005, p.11).

(Mardikanto, 2014) menyebutkan terdapat enam tujuan pemberdayaan masyarakat yang dianggap sesuai dengan pencapaian dalam program ini diantaranya adalah untuk perbaikan kelembagaan, usaha, pendapatan, lingkungan, kehidupan dan masyarakat. Untuk mencapai tujuan tersebut, diperlukan adanya partisipasi masyarakat dari setiap pelaksanaan pemberdayaan yang dilakukan untuk dapat merumuskan segala permasalahan yang ada pada masyarakat, sehingga pada akhirnya aksi pemberdayaan yang dilakukan tersebut dapat sesuai dengan kebutuhan dan harapan masyarakat. Sebagaimana yang diungkapkan oleh (Adi, 2003) bahwa pemberdayaan menekankan pada process goal, yaitu tujuan yang berorientasi pada proses yang mengupayakan integrasi masyarakat dan dikembangkan kapasitasnya guna memecahkan masalah secara kooperatif atas dasar kemauan dan kemampuan menolong diri sendiri (self help) sesuai prinsip demokratis. Adapun langkah-langkah program yang dilaksanakan yaitu sebagai berikut:

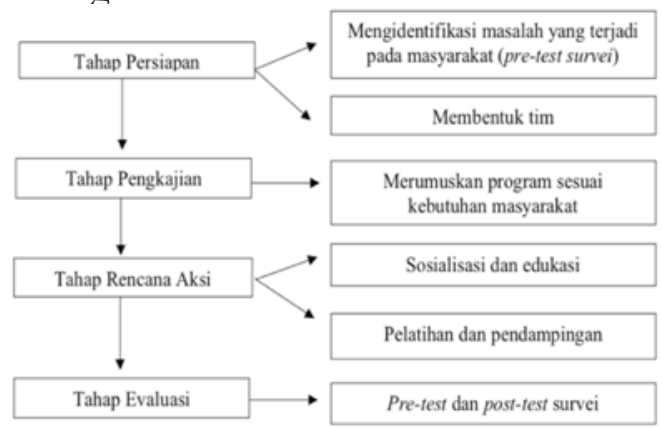

Gambar1: Langkah kegiatan pengabdian masyarakat 
Sebagai bagian dari perencanaan program, dilakukan rangkaian survei utama untuk mengetahui kegiatan apa saja yang akan dilakukan agar sesuai dengan kebutuhan masyarakat, yakni melalui analisa SWOT sebagai berikut:

\section{Strengths (Kekuatan)}

Bahwa banyak anak muda yang berpotensial dan kreatif dalam pembuatan produk. Dalam hal ini BGBJ juga memiliki peralatan yang dapat menunjang berjalannya usaha yang mereka miliki. Produk yang ditawarkan unik, orisinil dan bisa custom sesuai keinginan calon pelanggan, serta bahan dasar kayu yang digunakan sangat berkualitas, yang mana merupakan hasil daur ulang limbah kayu yang menumpuk di pembuangan Bantar Gebang.

2. Weakness (Kelemahan)

Jumlah SDM yang sedikit serta minimnya pengetahuan dan inisiatif SDM dalam memaksimalkan pemasaran produk membuat pencapaian penjualan produk terbatas. Adapun media atau saluran komunikasi yang digunakan juga masih kurang mumpuni.

\section{Opportunities (Peluang)}

Komunitas BGBJ memiliki peluang untuk memberikan lapangan pekerjaan baru bagi masyarakat di daerahnya dan juga dapat menjadi wadah bagi anak-anak remaja untuk belajar memulai usaha kreatif. Tidak hanya itu, founder BGBJ juga memiliki banyak koneksi dengan warga negara asing yang mana dapat menjadi sasaran untuk memperluas pemasaran produk.

4. Threats (Ancaman)

Kelemahan dari kemampuan SDM menjadi ancaman bagi keberlangsungan bisnis BGBJ yang tidak dapat berkembang secara maksimal. Seperti misalnya tidak memiliki inovasi hingga pada penutupan komunitas.

\section{HASIL DAN PEMBAHASAN}

Pelaksanaan program pemberdayaan ini dilakukan dengan melibatkan pendiri, peserta, hingga masyarakat setempat kegiatan pemberdayaan komunitas BGBJ. Program ini bertujuan untuk memberikan keterampilan serta keahlian dalam menghasilkan bahan limbah menjadi produk yang kreatif dan inovatif sampai pada proses pemasaran offline maupun online.

Sebelum melaksanakan program, dilakukan sebuah pre-test survei dengan penyebaran kuesioner dan wawancara kepada seluruh peserta dan pendiri komunitas BGBJ mengenai masalah-masalah yang terjadi pada keberlangsungan komunitasnya. Ditemukan bahwa selama empat tahun berjalannya bisnis daur ulang kayu, BGBJ mengakui bahwa produk yang dimilikinya belum dapat dikenal banyak oleh masyarakat luas sehingga capaian penjualan sangat minim. Resa Boenard selaku pendiri menyebutkan bahwa kendala utama yang terjadi ini salah satunya disebabkan oleh proses pemasaran produk. Pihaknya menyebutkan bahwa strategi 
pemasaran produk yang dilaksanakan hingga saat ini hanya dilakukan secara offline dengan bantuan Word of Mouth (WoM) dari masyarakat.

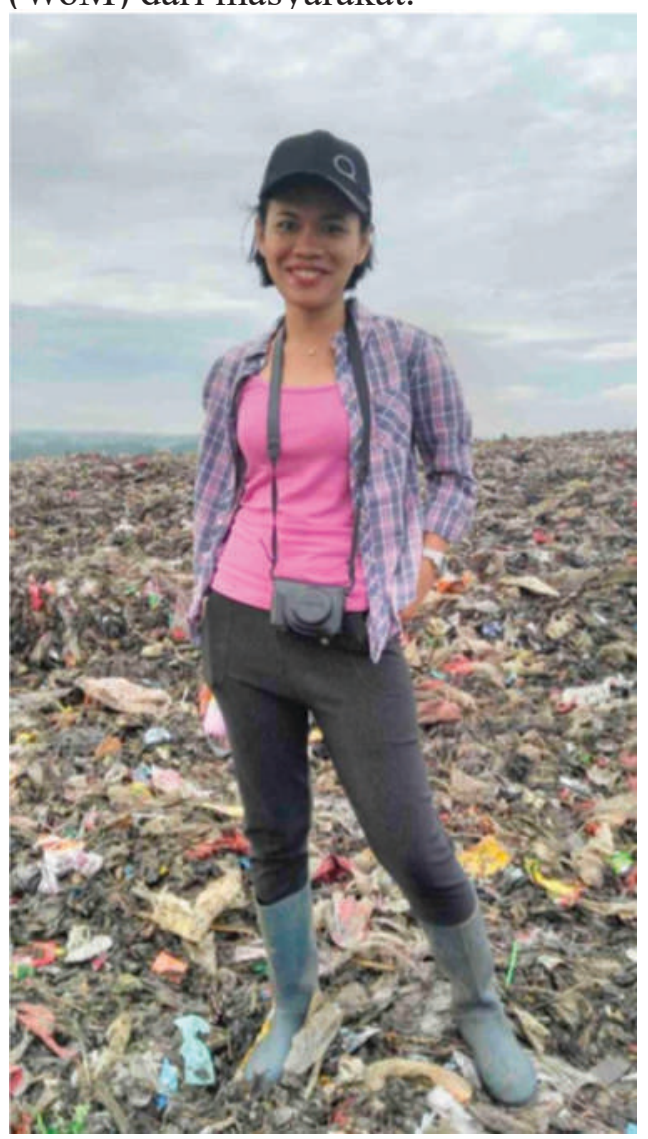

Gambar 2: Pendiri Komunitas BGBJ

Resa menyadari bahwa di era saat ini sudah waktunya untuk dapat beradaptasi dengan dunia digital. Dalam perkembangan dunia bisnis, pemanfaatan teknologi memiliki peranan yang sangat penting bagi kemajuan suatu komunitas, organisasi maupun perusahaan. Penerapan teknologi ini menyebabkan munculnya perubahan dan kebiasaan baru dalam dunia bisnis, baik dalam menjangkau khalayak, produksi hingga pemasaran. Sehingga diperlukan untuk mengindentifikasi dan mengelola keterampilan dan kemampuan yang dibutuhkan untuk dapat diterapkan dalam industri bisnis yang berkelanjutan (Pinariya \& Lemona, 2019).

Dalam hal ini, komunitas BGBJ mengakui bahwa produk

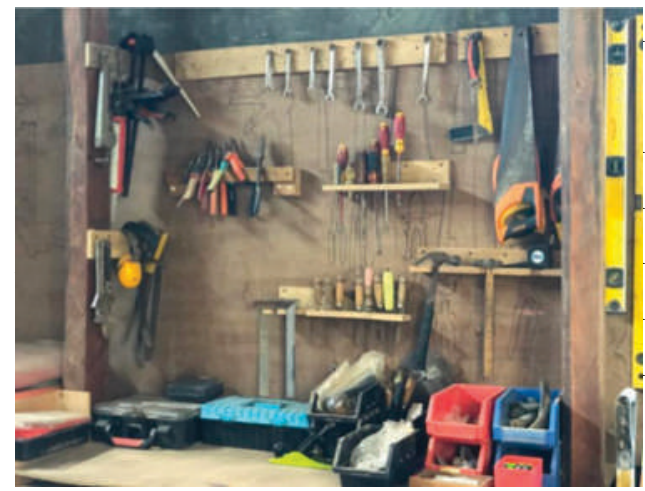

Gambar 3: Alat produksi BGBJ

Resa juga menyayangkan mentalitas dan inisiatif anak-anak Bantar Gebang yang masih sangat rendah, kebanyakan darinya justru berakhir menikah di usia yang sangat muda dan pulang kembali ke rumahnya tanpa bekal pengetahuan yang cukup. Selain itu, sebagian masyarakat juga belum berani untuk mengekspresikan diri padahal mempunyai potensi dan bakat yang luar biasa.

Dengan latar belakang permasalahan tersebut, dapat dinilai bahwa sebenarnya masih banyak harapan yang dapat digapai anak-anak muda di Bantar Gebang untuk belajar suatu hal yang baru dan sesuai dengan kebutuhan komunitas dan masyarakat, yaitu memulai usaha pembuatan hingga pemasaran produk kreatif baik secara offline, khususnya online dengan pemahaman yang maksimal tentang digital marketing. Program pemberdayaan ini akan dilakukan dalam beberapa tahapan yaitu dimulai dari tahap persiapan, merancang beberapa rangkaian kegiatan yang 
dijadikan sebagai aksi program yaitu dengan mengadakan sosialisasi dan edukasi, pelatihan dan pendampingan serta evaluasi dengan penjelasan sebagai berikut:

\section{Sosialisasi dan Edukasi}

Pelaksanaan kegiatan pemberdayaan ini diawali dengan melakukan pendekatan kepada masyarakat di sekitar Bantar Gebang. Pendekatan ini diarahkan melalui proses sosialisasi mengenai dasardasar digital marketing, teknik pengambilan foto, pembuatan konten hingga pada strategi pemasaran digital di media sosial dan platform e-commerce.

Gambar 4: Contoh Sosialisasi

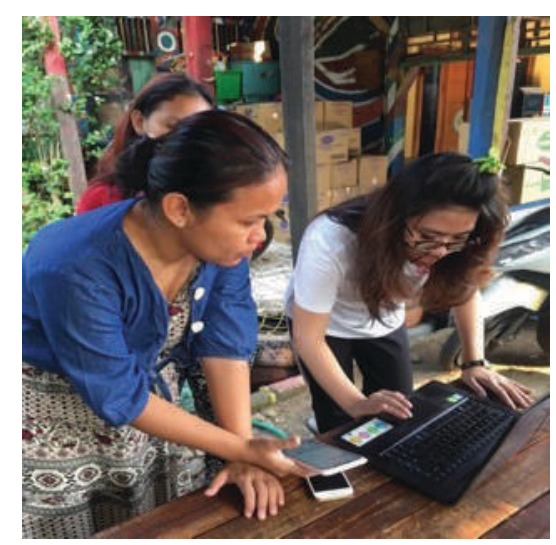

Pengoperasian Aplikasi Shopee

Dalam kegiatan ini, peserta dibentuk dalam suatu forum atau kelompok per minggunya untuk mempelajarimodul yang telah disusun, di mana terdapat beberapa materi yang disampaikan yaitu sebagai berikut:

\section{a. Digital Marketing di Media Sosial}

Untuk sesi pertama sampai ketiga, para peserta diberikan sosialisasi mengenai dasar-dasar digital marketing di media sosial (Instragram, Youtube dan Twitter).
Dalam hal ini, telah disusun beberapa topik untuk setiap sesinya yaitu sebagai berikut:

Tabel 1: Materi digital marketing di media sosial

\begin{tabular}{|c|c|c|}
\hline No. & Topik & Sesi \\
\hline 1. & $\begin{array}{l}\text { Pengenalan digital } \\
\text { marketing } \\
\text { - Apa itu digital } \\
\text { marketing? } \\
\text { - Jenis-jenis digital } \\
\text { marketing } \\
\text { - Metode digital } \\
\text { marketing }\end{array}$ & 1 \\
\hline 2. & $\begin{array}{l}\text { Menentukan target pasar } \\
\text { yang efektif }\end{array}$ & 2 \\
\hline 3. & $\begin{array}{l}\text { Strategi marketing di } \\
\text { media sosial } \\
\text { - Membuat akun } \\
\text { media sosial (Twitter, } \\
\text { Facebook dan } \\
\text { Instargram) } \\
\text { - Memahami dasar-dasar } \\
\text { tiap media sosial } \\
\text { - Membuat perencanaan } \\
\text { konten media sosial } \\
\text { yang menarik } \\
\text { - Penggunaan fitur } \\
\text { penjadwalan post } \\
\text { otomatis di media sosial } \\
\text { - Berkomunikasi } \\
\text { dengan audiens untuk } \\
\text { menambah relasi atau } \\
\text { memperluas pasar } \\
\text { - Menyusun strategi } \\
\text { promosi } \\
\text { - Mulai melakukan } \\
\text { penjualan } \\
\text { Lakukan pengukuran } \\
\text { efektivitas }\end{array}$ & 3 \\
\hline
\end{tabular}

b. Digital Marketing di

\section{E-Commerce}

Setelah memahami dasar-dasar digital marketing melalui media sosial, maka peserta diberikan sosialisasi mengenai media digital lainnyayaituplatforme-commerce. Dalam tahap ini, semua peserta diberikan penyuluhan mengenai dasar-dasar berbagai platform e-commerce yang dapat 
mendukung proses pemasaran produk BGBJ diantaranya seperti Shopee, Tokopedia, Lazada, dan lainnya selama tiga sesi. Setelah memahami satu persatu, peserta diberikan kesempatan untuk melakukan voting platform e-commerce terbaik yang dinilai sangat sesuai dengan kebutuhan komunitas BGBJ, yakni Shopee. Selain pengaplikasiannya mudah, berdasarkan riset terbaru iPrice (Triwijanarko, 2019), Shopee merupakan platform e-commerce yang dinobatkan sebagai aplikasi e-commercemobile denganjumlah pengunduh terbanyak yang mana hal ini dapat menjadi peluang bagi BGBJ untuk mengembangkan pemasaran produknya.

Dalam hal ini juga telah disusun tiap topik untuk setiap sesinya serta gambaran modul yang digunakan sebagai bahan pembelajaran untuk peserta yaitu sebagai berikut:

Tabel 2: Materi digital marketing

e-commerce

\begin{tabular}{|c|c|c|}
\hline No. & Topik & Sesi \\
\hline 1. & $\begin{array}{l}\text { Dasar-dasar tiap } \\
\text { e-commerce (Shopee, } \\
\text { Tokopedia, dan Lazada) }\end{array}$ & 1 \\
\hline 2. & $\begin{array}{lr}\text { Voting salah satu } \\
\text { e-commerce } & \text { yang } \\
\text { difokuskan untuk } \\
\text { komunitas (Shopee) }\end{array}$ & 2 \\
\hline 3. & $\begin{array}{l}\text { - Tata cara pendaftaran } \\
\text { akun Shopee } \\
\text { - Tata cara pembayaran } \\
\text { di Shopee dst } \\
\text { hingga pada proses } \\
\text { pengiriman produk }\end{array}$ & 3 \\
\hline
\end{tabular}

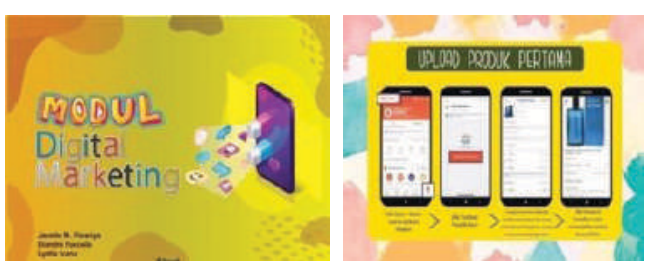

Gambar 5: Tampilan modul digital marketing untuk media sosial dan ecommerce

\section{Pelatihan dan Pendampingan}

Setelah diberikan sosialisasi mengenai beberapa materi yang disampaikan, untuk dapat dipahami secara praktek dan teknisnya, para peserta akan diberikan beberapa pelatihan dan pendampingan pada kegiatan yang sudah dilakukan serta kegiatan pendukung lainnya seperti cara pengambilan foto, pengeditan foto, dan pembuatan konten. Kegiatan ini dilakukan pada sesi ke enam hingga terakhir.

\section{a. Pelatihan dan Pendampingan} Media Sosial

Setelah memahami penggunaan mediasosial,parapesertadiberikan pelatihandanpendampinganuntuk pengoperasian masing-masing media sosial yang digunakan. Pelatihan dan pendampingan ini antara lain adalah tentang tata cara follow mem-follow, cara penggunaan Instagram story, pengelolaan feeds, penggunaan hastag, pembuatan konten, hingga pada cara pengunggahan foto/ video produk. 

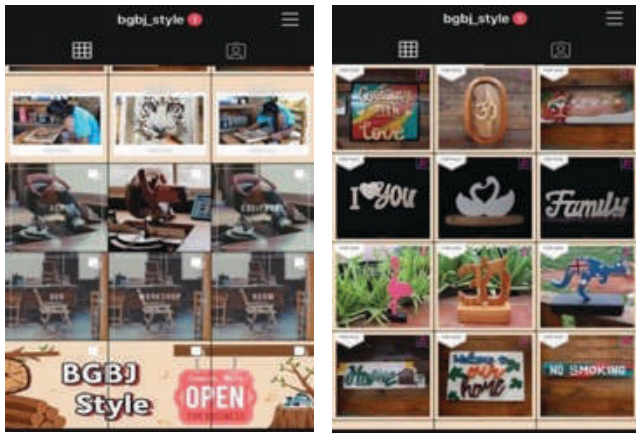

Gambar 6: Tampilan feeds Instagra,@bgbj_style

Setelah rangkaian pelatihan dan pendampingan dilakukan, para peserta membuat strategi promosi dengan menggunakan buzzer dengan target blasting Instagram stories sebanyak 100 akun dengan menyebutkanakun@bgbj_styledi dalamnya. Hal ini dilakukan agar calon pelanggan dapat langsung terhubung ke akun media sosial terkait.

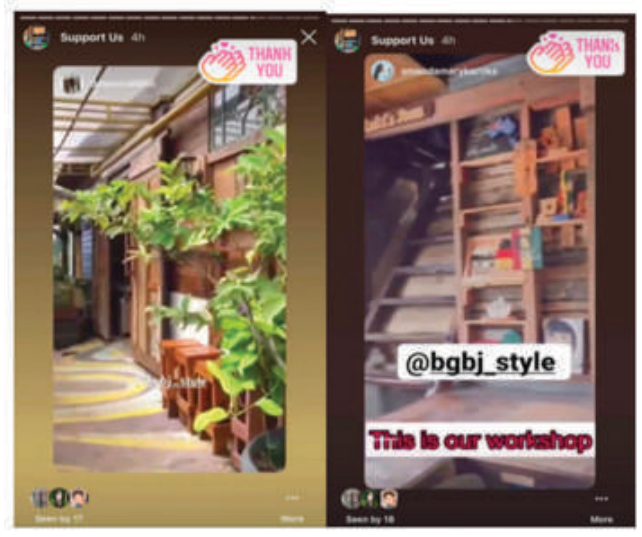

Gambar 7: Aktivitas Insta Story BGBJ

\section{b. Pelatihan dan Pendampingan E-Commerce}

Setelah memahami dasar-dasar dari setiap e-commerce, para peserta diberikan pelatihan dan pendampingan lebih lanjut mengenai detail teknis pengoperasian akun Shopee. Pengenalan pertama, para peserta diberikan pemahaman secara praktek tentang tata cara registrasi, membuat konten deskripsi produk, promosi, percakapan dengan customer melalui kolom chat, menambah dan menghapus ketersediaan produk, cara pengemasan yang rapih, pengiriman produk melalui kurir hingga pada proses pembayaran/ penarikan dana.

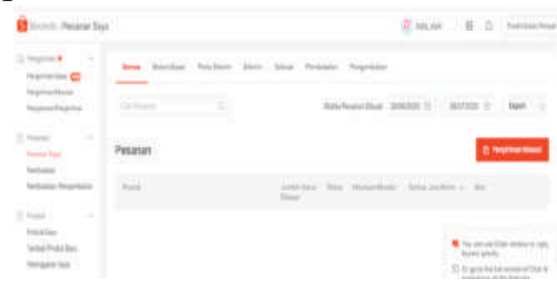

Gambar 8: Akun Shopee BGBJ

Setelah memahami pengoperasian Shopee secara praktek, para peserta dapat menerapkannya secara real dengan memanfaatkan produk-produk yang tersedia sebagai bagian dari tester dengan cara mencoba untuk memesan produk yang sudah tersedia dalam akun Shopee BGBJ dan dikirimkan ke alamat yang dituju sampai pada proses pembayaran untuk memastikan para peserta dapat mengoperasikan akun Shopee nya dengan baik, tidak hanya sekedar praktek.

\section{c. Pelatihan dan Pendampingan} Pengambilan Foto Produk

Selain fokus pada pemasaran produk, para peserta juga diberikan pelatihan dan pendampingan lainnya sebagai kegiatan pendukung untuk keberhasilan produk BGBJ, yaitu pengambilan foto produk. Dalam hal ini, para peserta diberikan 
tips dan trik pengambilan foto dengan angel yang bagus dengan memberikan sarana studio mini dan pencahayaan agar foto yang dihasilkan memiliki kualitas yang baik.

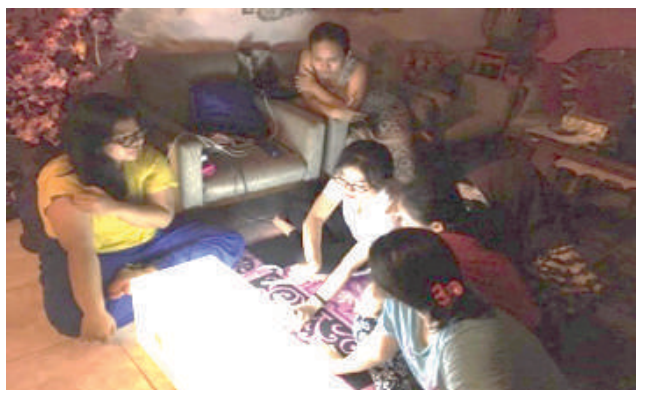

Gambar 9: Pelatihan dan pendampingan pengambilan foto produk

\section{d. Pelatihan dan Pendampingan Pengeditan Foto Produk}

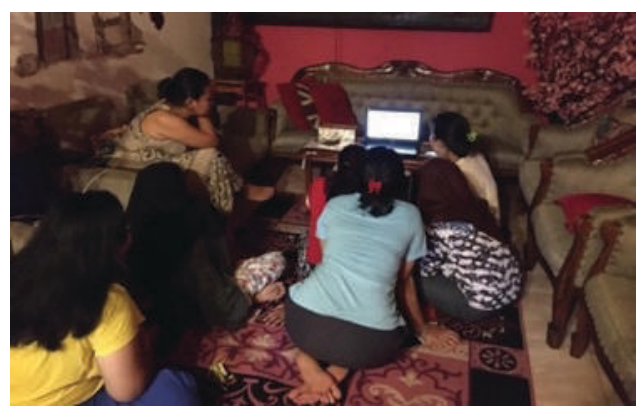

Gambar 10: Pelatihan dan pendampingan pengeditan foto produk

Setelah melakukan pengambilan foto, para peserta diberikan pelatihan pengeditan foto dengan tujuan agar foto yang nantinya akan diunggah ke media sosial dan e-commerce menjadi lebih menarik. Hal ini menjadi salah satu strategi tersendiri untuk dapat menarik perhatian dari calon para pelanggan. Kebanyakan calon pelanggan akan lebih terpersuasif pada tampilan produk yang menarik, tanpa mengurangi tampak keaslian produknya. Pelatihan pengeditan foto yang dilakukan antara lain cara pengaturan cahaya, pengaturan warna dan lain sebagainya melalui Microsoft Power Point dan aplikasi design Canva.

\section{e. Pelatihan dan Pendampingan} Pembuatan Konten

Setelah menghasilkan gambar produk yang baik, selanjutnya kami memberikan pendampingan pembuatan konten. Isi dari konten tersebut mengandung informasi terkait produk secara detail seperti bahan, ukuran, fungsi, hastag, dan lain sebagainya. Setelah pembuatan konten, peserta diberikan pemahaman tentang penyesuaian template dan warna yang seragam agar tampilan produk pada akun e-commerce dan media sosial tersusun dengan rapih. Selanjutnya juga diberikan pemilihan jam yang tepat untuk pengunggahan konten atau foto seperti pagi hari sekitar pukul 07:00-9:00, siang sekitar pukul 12:00-14:00, sore dan malam hari sekitar pukul 17:00-21:00 sehingga ada pengaturan jeda waktu memposting.

\section{Evaluasi}

Setelah menjalani serangkaian tahapan sosialisasi, pelatihan dan pelatihan selama tiga bulan, dilakukan tahap evaluasi dengan pre-test dan post-test survey untuk mengetahui perkembangan dari kegiatan yang dilakukan pada pada peserta komunitas BGBJ dan keputusan memanfaatkan platform digital marketing dalam 
menjalankan usahanya.

Tabel 3: Perbandingan pre-test dan post-test survey (notes: mohon maaf karena table terlalu banyak jadi saat di layout menjadi berantakan)

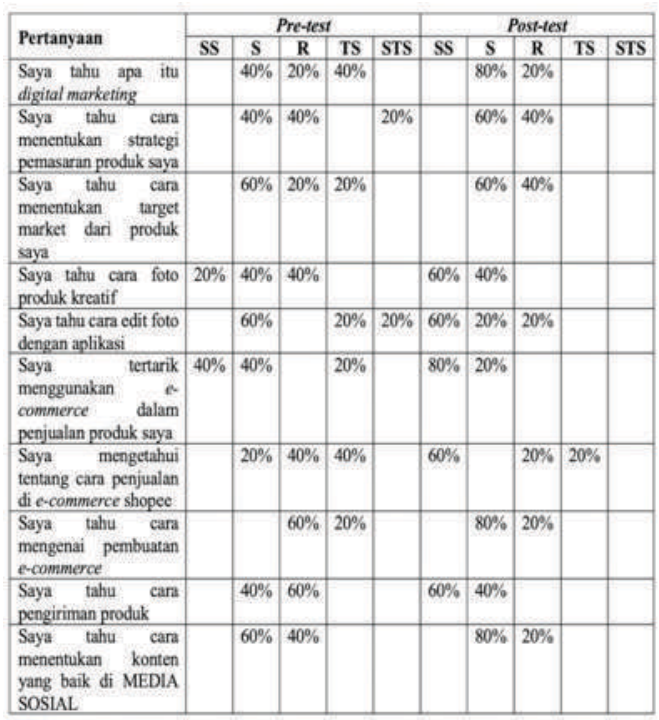

1. Pre-test

Hasil pre-test survei yang dihasilkan dari lembar kuesioner menunjukkan bahwa pemahaman peserta BGBJ mengenal digital marketing masih sangat minim. Namun untuk tata cara pengambilan foto produk sebagian besar sudah baik dikarenakan sebelumnya sudah mendapatkan seminar fotografi dari volunteer yang saat itu membantu BGBJ.

Kemudian terkait e-commerce, para peserta terlihat sangat antusias untuk menggunakan Shopee sebagai media pemasaran produknya meskipun belum memahami tentang cara pembuatan akun hingga pada pengoperasian lainnya. Lalu untuk media sosial yang sering digunakan yakni Instargram memang sudah digunakan sejak awal, namun masih banyak sebagian yang belum memahami bagaimana cara membuat konten yang menarik.

2. Post-test

Setelah rangkaian kegiatan sosialisasi, pelatihan dan pendampiang dijalankan, langkah selanjutnya melakukan posttest survei dengan melakukan penyebaran kuesioner yang digunakan saat pre-test untuk mengetahui perkembangan yang terjadi. Untuk mengetahui secara mendalam, juga dilakukan wawancara sebagai bentuk pengulangan materi atau brainstorming. Hasil menunjukkan bahwa sebagian besar peserta sudah memahami digital marketing dengan baik, namun masih belum dapat menentukan strategi pemasaran dan target market secara maksimal.

Kemudian untuk pengoperasian e-commerce Shopee dan media sosial, pengambilan foto, pengeditan, serta pembuatan konten sudah dapat berjalan dengan baik dikarenakan telah menjalani rangkaian praktek yang membuat para peserta mudah untuk menerapkannya kembali secara mandiri.

\section{SIMPULAN}

Hasil evaluasi pre-test dan posttest survei menunjukkan bahwa kegiatan yang dilakukan dalam pemberdayaan melalui pelatihan dan pengenalan digital marketing pada komunitas BGBJ khususnya anak- 
anak remaja di Bantar Gebang dapat diterima dengan baik oleh seluruh peserta. Sebagian kecil peserta mengakui bahwa dirinya masih belum memahami strategi pemasaran secara maksimal sehingga masih perlu arahan dan bimbingan lebih lanjut.

Sedangkan sebagian besar lainnya mengaku sudah cukup memahami dan bisa menjalankan praktek dari materi pelatihan yang diberikan, sehingga diharapkan mampu beradaptasi dengan dunia digital dalam menghadapi era 4.0. Berdasarkan praktek yang sudah dijalankan, bisa dirasakan bahwa semakin banyak orang yang mulai memahami bahwa di Bantar Gebang terdapat suatu komunitas yang peduli akan lingkungan dan ekonomi masyarakat dengan segudang kegiatan positif dan produktifuntukkelangsungan kegiatan ramah lingkungan. Dengan adanya program pemberdayaan masyarakat ini, diharapkan masyarakat maupun komunitas kecil dapat saling bahu membahu untuk dapat menciptakan lingkungan dan ekonomi yang aktif dan produktif.

\section{DAFTAR PUSTAKA}

Adi, I. R. (2003). PemikiranPemikiran dalam Pembangunan Kesejahteraan Sosial. Seri Pemberdayaan Masyarakat 02. Fakultas Ekonomi Universitas Indonesia.

Christiawan, R. (2019). Tanggung Jawab Endorser. SWA. https:// swa.co.id/swa/my-article/ tanggung-jawab-endorser

Fakhrana, R. S. (2015). TPST Bantargebang dari Waktu ke Waktu. CNN Indonesia. https:// www.cnnindonesia.com/ nasional/20151104214119-2089538/tpst-bantargebang-dariwaktu-ke-waktu.

Harahap, L. (2019). Sampah Jakarta Bikin Resah. Merdeka.Com. https://www.merdeka.com/ jakarta/sampah-jakarta-bikinresah.html

Jakarta Kota Metropolitan dengan Budaya Kampung. (2013). https://www.kompasiana.com/ delianasetia/552a26eef17e6 1 ed 63 d623be/jakarta-kotametropolitan-dengan-budayakampung\#

Mardikanto, T. (2014). Corporate Social Responsibility (Tanggung Jawab Sosial Korporasi). Alfabeta.

Mulyadi, D. (2016). Mengembangkan Kepedulian Masyarakat TPA Bantar Gebang Akan Pentingnya Pendidikan dalam Meningkatkan Taraf Kehidupan Merdeka. STIE Pertiwi Bekasi.

Nursastri, S. A. (2019). Jakarta Hasilkan 7.700 Ton Sampah per Hari. https://sains.kompas.com/ $\mathrm{read} / 2019 / 11 / 01 / 190700323 /$ jakarta-hasilkan-7.700-tonsampah-per-hari?page $=$ all

Pinariya, J. M., \& Lemona, M. (2019). Literasi dan Sosialisasi Internet Ramah Anak. Jurnal Abdi Moestopo, 2(2), 50-56.

Triwijanarko, R. (2019). Riset: Shopee Jadi Platform e-Commerce Nomor Satu di Indonesia. https://marketeers.com/shopeejadi-platform-e-commercenomor-satu-di-indonesia/

Yunia, A., \& Pinariya, J. M. (2019). Rumah Kreatif dan Inovasi Sebagai Program Pemberdayaan Masyarakat Kampung Muara Bahari. Journal of Servite, 1(1), 25. https://doi. org/10.37535/102001120193 